\title{
ANALISA UKURAN DAN LAJU ALIR BATUBARA PADA BOILER PULVERIZER PLTU 660 MW
}

\author{
Ruly Bayu Sitanggang1), Eko Supriyanto ${ }^{2)}$ \\ ${ }^{1,2}$ Bidang Riset Sistem Pembangkitan, PT (PLN) Persero Research Institute \\ Email: rully.bs@pln.co.id ${ }^{1)}$ \\ Nomor Telp : +62 85220055339 \\ Asal Negara: Indonesia
}

\begin{abstract}
ABSTRAK
Pulverizer adalah salah satu peralatan penting di pembangkit listrik tenaga uap. Partikel batubara yang masih terbakar di area back pass boiler akan mengakibatkan penurunan efisiensi sehingga laju aliran campuran udara dan batubara di saluran pipa bahan bakar perlu diseimbangkan. Penelitian ini dilakukan pada PLTU Batubara tipe pulverized coal dengan kapasitas 660 Megawatt yang menggunakan enam pulverizer. Aliran keseimbangan bahan bakar diperiksa menggunakan uji dirty air dan pengambilan sampel ukuran batubara dilakukan dengan metode isokinetic. Dalam pengujian dirty air tiga pulverizer masih mengalami turbulensi, menyebabkan pengukuran kecepatan udara menjadi kurang akurat dan hasil pengujian dirty air pada tiga pulverizer lainnya menunjukkan hasil baik dengan kecepatan antar pipa batubara seragam. Lokasi tap test pada pulverizer D, C, dan A disarankan dipindahkan ke jarak sekitar lima kali diameter pipa dari hambatan. Temperatur keluaran seluruh pulverizer pada masih lebih rendah dari nilai standard. Karena tidak ada orifice di dalam pipa batubara, menaikkan suhu keluaran pulverizer ke $65{ }^{\circ} \mathrm{C}$ dapat dilakukan untuk meningkatkan keseimbangan kecepatan batubara. Secara keseluruhan, pengujian kehalusan sampel batubara menunjukkan hasil sesuai rekomendasi, dengan nilai kehalusan rata-rata lolos saringan 200 mesh pulverizer A, B, C, D, E, dan F masingmasing adalah $82,12,83,24,73,96,79,13,68,14$, dan $78,43 \%$ berat.
\end{abstract}

Kata kunci: pulverizer, isokinetic, pengujian dirty air, coal balancing.

\begin{abstract}
Pulverizers are one of the most critical pieces of equipment in a pulverized coal steam power plant. Coal particulates that continue to burn in the back pass result in decreased boiler efficiency. This study was carried out at a $660 \mathrm{MW}$ power plant with six pulverizers. A dirty air test and isokinetic sample are used to investigate the fuel balance. Some coal lines in the dirty air test for three pulverizers still had turbulence, causing the dirty air velocity measurements less accurate. Because the velocity of dirty air between coal pipes is uniform, the results of the dirty air test on the other three pulverizers are excellent. The temperature in the six-pulverizer outlet is still below the required value. The test position on the $D, C$, and A pulverizers should be moved to a distance five times the coal pipe. Because there is no orifice in the coal pipe, raising the pulverizer outlet temperature to $65^{\circ} \mathrm{C}$ may improve the flow balance in each coal pipe. Overall, the fineness testing revealed that they were still within the recommended range, with an average values of 82.12, 83,24, 73.96, 79.13, 68.14 and 78.43 wt percent for pulverizer $A, B, C, D, E$, and $F$, respectively.
\end{abstract}

\section{Keywords: pulverizer, isokinetic, dirty air test, coal balancing.}

\section{PENDAHULUAN}

Salah satu peralatan terpenting pada pembangkit listrik tenaga uap (PLTU) batubara yang menggunakan boiler tipe pulverized coal (PC) adalah pulverizer. Suhu gas keluar ruang bakar yang tinggi (FEGT) (Wiatros-Motyka, 2016), proses pembakaran yang tidak baik, temperatur permukaan superheater yang tinggi (Nugroho \& Ichsani, 2019), peningkatan tara kalor pembangkit (Prasetyo \& Prabowo, 2019), laju alir air pendingin uap superheat, dan pemborosan pada air pengisi boiler adalah permasalahan yang sering dialami boiler dengan performa pulverizer yang tidak baik. Disisi lain buruknya performa pulverizer juga dapat mengakibatkan pembentukan terak dan lapisan pengotor pada permukaan pipa boiler (Schreiber et al., 2008). Peningkatan efisiensi energi di PLTU batu bara dapat dicapai dengan mengoptimalkan distribusi bahan bakar, keseimbangan aliran udara primer dan batubara pada saluran bahan bakar yang dapat dikendalikan atau diperbaiki. (Żymełka et al., 2017). Berkurangnya efisiensi boiler dan meningkatnya pembentukan terak serta lapisan deposit pada permukaan pipa boiler disebabkan oleh partikel batubara yang terbakar di area backpass setelah tidak habis terbakar di area ruang bakar boiler. Selain itu pengaturan pada pulverizer serta laju aliran udara, harus dilakukan untuk mencapai potensi reduksi 
emisi NOx. (Li \& Yao, 2017). Pada partikel batubara yang berada di udara yang mengalir pada kecepatan tertentu, maka semakin tinggi momentum yang dimilikinya, akan semakin mudah terjadi pemisahan antara partikel batubara halus dengan partikel batubara yang berukuran besar dan terjadi ketidakseimbangan pada laju aliran bahan bakar. Dengan menggunakan batubara yang berukuran partikel kecil atau halus, waktu pembakaran pada ruang bakar akan memadai untuk terjadinya pembakaran seluruh partikel batubara tanpa mencapai area backpass atau area superheater sehingga meningkatkan efektifitas proses pembakaran pada boiler dan menurunkan biaya operasi (POWER, 2011, p. 101). Proporsi batubara dengan ukuran besar pada udara pembakaran akan menyebabkan penurunan laju aliran udara pada saluran pembakaran. Untuk menjaga kesetimbangan laju alir udara pada saluran bahan bakar, perlu dilakukan pengujian dirty air pada saluran bahan bakar saat PLTU beroperasi namun kegiatan tersebut umumnya jarang dilaksanakan pada PLTU yang telah beroperasi. Jika terjadi gangguan yang menyebabkan perubahan pada ukuran batubara yang dihasilkan pulverizer maka cenderung akan menyebabkan sistem distribusi batu bara akan tidak efisien, maka diperlukan untuk membuat suatu baseline performa dari kesetimbangan distribusi batubara di tiap pipa saluran batubara dari pulverizer menuju boiler yang dapat dilakukan dengan monitoring laju alir, ukuran batubara dan kecepatan batubara (POWER, 2010).

Pemeriksaan laju alir batubara dan pengujian ukuran partikel batubara secara isokinetic merupakan hal yang penting, namun referensi yang menjelaskan proses pengujian dirty air dan isokinetic sampling pada PLTU subcritical skala menengah maka pada studi ini akan dibahas proses pengujian dirty air dan pengamatan ukuran batubara melakukan isokinetic untuk melihat kesetimbangan distribusi bahan bakar antara tiap pipa distribusi batubara dari pulverizer ke boiler. Studi ini dilakukan pada PLTU kapasitas 660 MW yang terletak di Paiton, Jawa Timur, Indonesia. Diharapkan makalah ini dapat dijadikan referensi jika akan dilaksanakan pengujian serupa di PLTU lain.

\section{METODE}

Boiler yang digunakan pada pengujian ini adalah boiler tipe sirkulasi paksa, burner yang terletak pada bagian sisi, aliran udara yang seimbang, menggunakan reheat, dapat beroperasi pada tekanan uap konstan ataupun bervariasi dan menggunakan bahan bakar batubara yang telah dihaluskan menggunakan pulverizer. Adapun metode penelitian yang dilakukan pada studi ini dapat dilihat pada Gambar 1. Setiap pulverizer di set untuk beroperasi pada rating maksimum, kemudian pada setiap coal pipe dilakukan pengujian dirty air test. Setelah itu dilakukan perhitungan delta tekanan untuk penentuan kecepatan isokinetic pengambilan sampel batubara. Setelah itu kemudian dilakukan pengukuran distribusi ukuran batubara dari tiap pulverizer dan dilakukan analisis hasil. Terdapat 24 burner yang terletak pada empat sisi boiler dengan mode pembakaran tangential. Sistem pulverizer yang digunakan menggunakan sistem udara primer untuk transport bahan bakar ke boiler dengan enam buah bowl pulverizer tipe HP 1163 yang dioperasikan pada kapasitas maksimum saat pengujian masing - masing pulverizer.

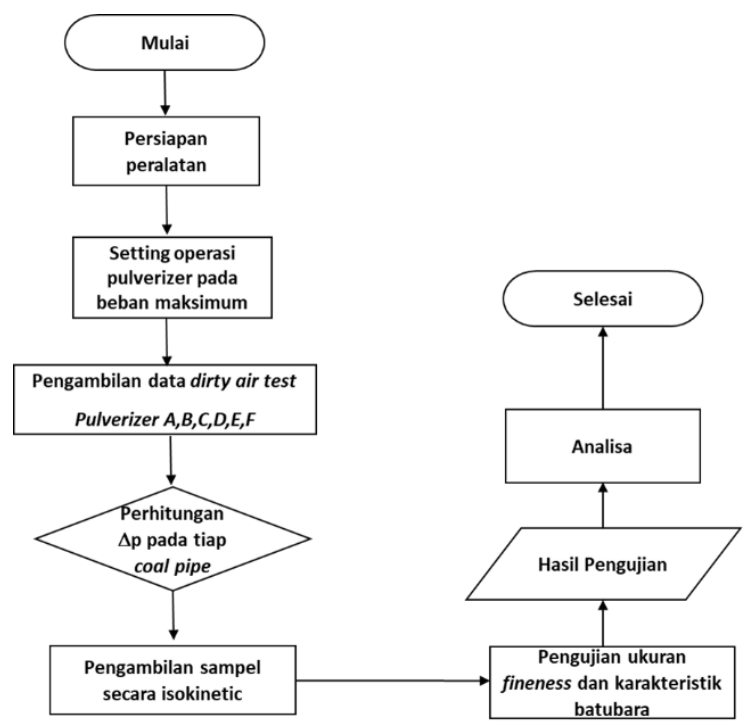

Gambar 1. Metode penelitian

Setiap pulverizer memiliki empat pipa keluaran untuk distribusi batubara menuju boiler yang dinamakan coal pipe. Spesifikasi dari pulverizer ditunjukkan pada Tabel 1 .

Tabel 1

Spesifikasi pulverizer

\begin{tabular}{|c|c|c|c|c|c|c|}
\hline Tipe & \multicolumn{6}{|c|}{$\begin{array}{l}\text { HP1163 } \\
\text { bowl -type medium- } \\
\text { speed }\end{array}$} \\
\hline Kapasitas & \multicolumn{6}{|c|}{$88.4 \mathrm{~T} / \mathrm{h}$} \\
\hline $\begin{array}{l}\text { Ukuran batubara } \\
\text { masuk }\end{array}$ & \multicolumn{6}{|c|}{$\begin{array}{l}0 \sim 35 \mathrm{~mm}(95 \%), \\
35 \sim 50 \mathrm{~mm}(5 \%)\end{array}$} \\
\hline Kelembaban batubara & \multicolumn{6}{|c|}{33} \\
\hline HGI batubara & \multicolumn{6}{|c|}{50} \\
\hline Pembukaan & A & B & $\mathrm{C}$ & $\mathrm{D}$ & $\mathrm{E}$ & $\mathrm{F}$ \\
\hline Classifier & 5 & 5 & 5 & 6 & 7 & 5 \\
\hline
\end{tabular}

Pada saat PLTU operasi dengan beban maksimum, lima pulverizer akan beroperasi dan satu pulverizer akan standby. Skema susunan dari pulverizer dapat dilihat pada Gambar 2. Temperatur udara sekitar, tekanan udara dan kelembaban relatif diambil setiap lima menit saat pengujian dilakukan menggunakan sensor portable yang dapat menyimpan data secara otomatis (data logger). 


\subsection{Pengujian Dirty air}

Pada setiap coal pipe terdapat satu tapping pengujian untuk memasukkan probe pengujian. Pengujian dilakukan pada sisi vertical tiap coal pipe. Sebelum dilakukan pengujian dirty air, data temperatur dan tekanan statis dalam coal pipe diukur menggunakan termokopel tipe $\mathrm{K}$ dan sensor tekanan statis seperti ditunjukkan pada Gambar 3.Pengukuran temperatur dilakukan pada tiga titik yaitu dua posisi ujung dan satu posisi tengah. Diameter dalam coal pipe adalah $70 \mathrm{~cm}$ dan sesuai rekomendasi ada 12 titik pengukuran sesuai ASME PTC 4.2 (ASME, 1969). Jarak titik pengukuran dapat dilihat pada Gambar 4

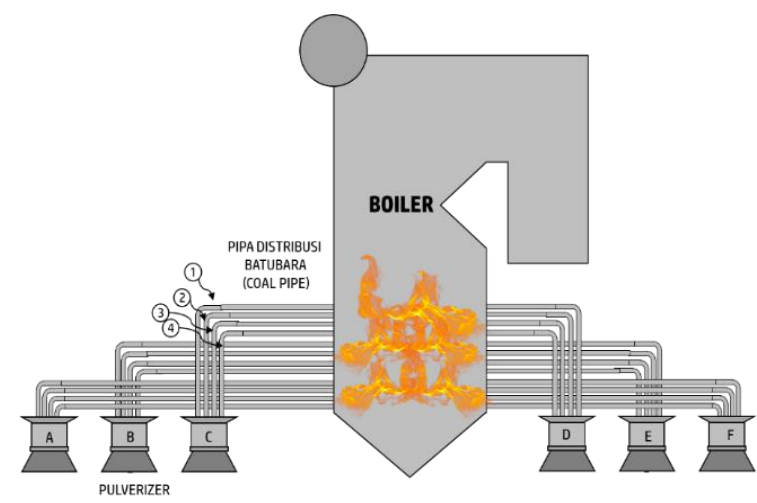

Gambar 2. Layout pulverizer pada PLTU

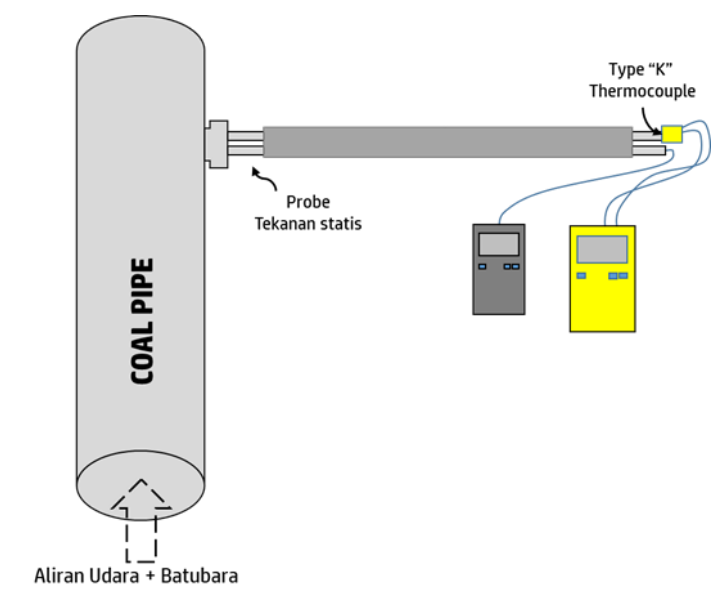

Gambar 3. Skema pengukuran temperatur dan tekanan statis dalam coal pipe.

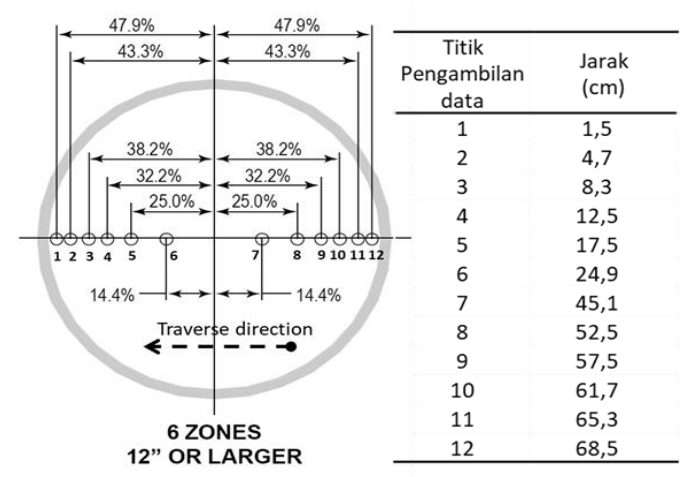

Gambar 4. Jarak titik pengambilan data pada coal pipe.
Kecepatan campuran udara dan partikel udara pada tiap coal pipe dilakukan untuk menentukan laju pengambilan sampel secara isokinetic. Skema pengujian dirty air ditunjukkan pada Gambar 5. Probe yang digunakan memungkinkan untuk pengambilan data dilakukan pada lingkungan dengan kandungan debu yang tinggi sehingga menurunkan kemungkinan probe untuk berhenti berfungsi. Dua saluran selang untuk tekanan tinggi dan tekanan rendah menghubungkan probe dirty air ke manometer 10 inci yang memiliki kemiringan. Pada saat pengujian probe akan digerakkan sesuai jarak dari dua belas titik yang telah ditentukan pada Gambar 4, kemudian tekanan yang terbaca pada manometer akan dicatat.

Kecepatan campuran udara dan batubara (dirty air velocity) kemudian dihitung menggunakan persamaan:

Density $(\rho)=\frac{530}{460+T} \times \frac{B_{P}+\frac{s_{P}}{13.6}}{29.92} \times 0.075$

Note:

$\mathrm{T}=$ Temperature dalam coal pipe $(\mathrm{F})$

$\mathrm{Bp}=$ Tekanan udara (inch $\mathrm{Hg}$ )

$\mathrm{Sp}=$ Tekanan statis pada coal pipe (inch

Dirty air velocity $=1096 \frac{\mathrm{Avg} \sqrt{v h}}{\pi} \times K$

$\operatorname{Avg\sqrt {vh}}=\frac{\sum_{v h=1}^{n} \sqrt{v h}}{n}$

Note:

$\mathrm{K}=$ Faktor Probe $\mathrm{K}$

$\mathrm{vh} \quad=\quad$ Velocity head (inch wc)

$\mathrm{n}=$ Jumlah titik pengambilan data

\subsection{Pengambilan sampel batubara secara Isokinetic}

Setelah pengukuran dirty air velocity pada tiap coal pipe dilakukan pengambilan sampel batubara secara isokinetic. Titik pengambilan sampel yang digunakan sama dengan titik pengujian dirty air.

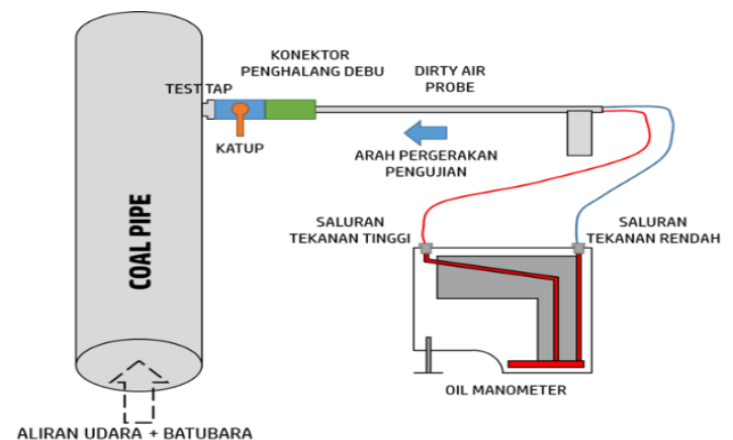

Gambar 5. Skema pengujian dirty air 
Skema dari pengambilan sampel secara isokinetic ditunjukkan pada Gambar 6. Perbedaan tekanan pada orifice saat pengambilan sampel dihitung dengan menggunakan persamaan:

$$
\Delta P=1.573 \times(\operatorname{avg} \sqrt{v h})^{2} x(K)^{2}
$$

Perbedaan tekanan pada setiap titik akan disesuaikan dengan hasil perhitungan untuk memastikan sampel batubara terambil secara isokinetic.

Pada saat pengujian perbedaan tekanan tersebut dimonitor dan dijaga konstan sesuai dengan hasil perhitungan di setiap coal pipe. Untuk mengatur perbedaan tekanan tersebut digunakan suplai udara dari kompresor alat bantu PLTU yang diatur menggunakan katup. Waktu pengumpulan sampel pada setiap titik adalah 20 detik sehingga waktu total pengambilan sampel untuk tiap coal pipe adalah empat menit. Setelah semua sampel dari titik terkumpul pada tabung sampel, sampel batubara kemudian dikumpulkan dalam kantong uji dan diberikan penamaan sesuai lokasi pengambilan sampel. Distribusi persentase ukuran batubara yang diambil kemudian akan berdasarkan ASTM D-197 (ASTM, 2007) dengan menggunakan saringan dengan ukuran mesh 48, 100, 150 dan 200 seperti dicantumkan juga pada petunjuk pengujian performa pembangkit listrik oleh ASME (ASME, 2010).

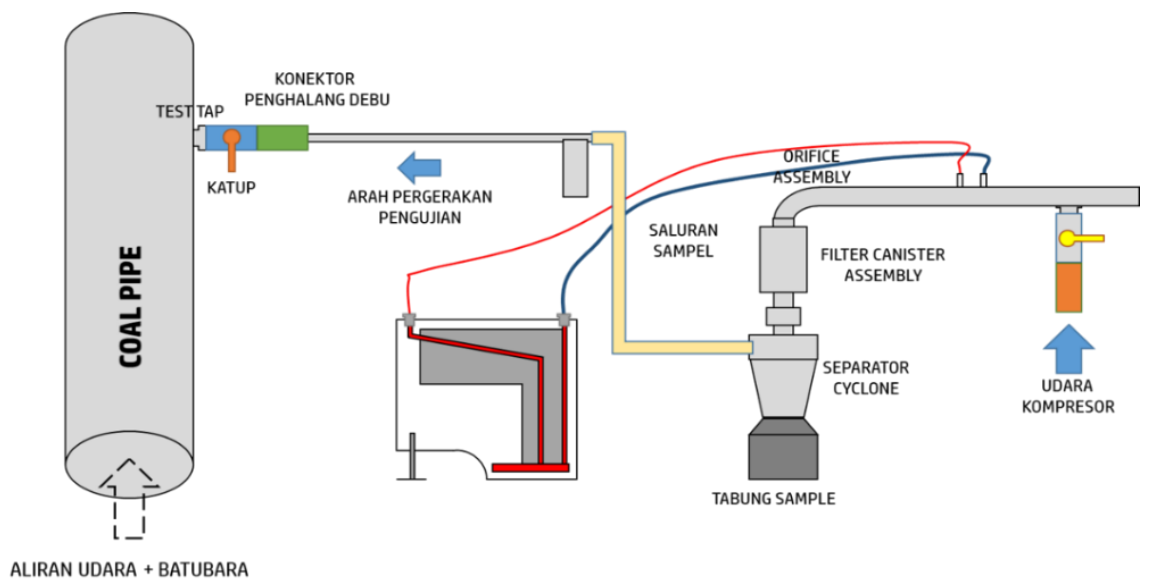

Gambar 6. Skema pengambilan sampel batubara secara isokinetic

\section{HASIL DAN PEMBAHASAN}

Hasil Dirty air Test Pulverizer A ditunjukkan pada Velocity dirty air pada coal pipe 1, 2, 3 dan 4 secara urut sebesar 23,53,33,61, 33,83 dan 29,18 $(\mathrm{m} / \mathrm{s})$ dengan rerata dirty air velocity sebesar 30,04 $\mathrm{m} / \mathrm{s}$. Berdasarkan nilai dirty air velocity diatas maka didapat velocity deviation terhadap rerata velocity untuk coal pipe 1, 2, 3 dan 4 sebesar -21,66, 11,88, 12,62 dan 2,85 (\%).

Rekomendasi deviasi pada coal pipe adalah $\pm 5 \%$ pada masing - masing coal pipe terhadap rerata velocity (Storm \& Consultant, 2009) (Brown \& McClellan, 2017).

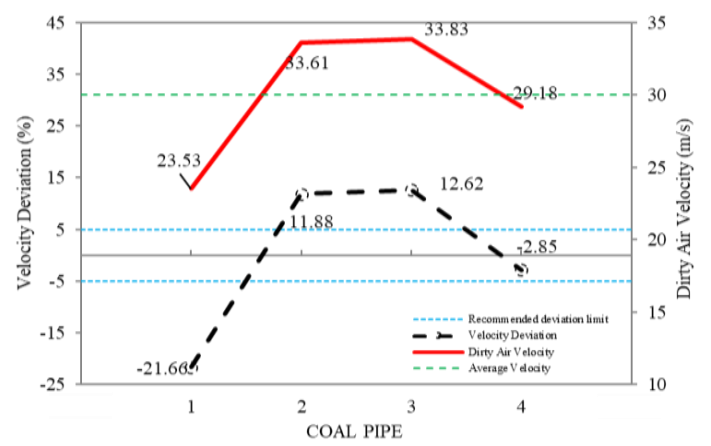

Gambar 7. Grafik dirty air velocity pulverizer A
Pada coal pipe 1 terjadi under velocity karena nilai deviasi sebesar $-21,66 \%$ terhadap rata-rata. Pada coal pipe 1 aliran cenderung kurang stabil, sehingga pembacaan tekanan dinamis kurang akurat. Untuk mendapatkan data yang lebih akurat, posisi tap test perlu dipindahkan menjauh dari hambatan aliran seperti belokan pada pipa. Temperatur keluaran mill A dari DCS menunjukkan 59,3 ${ }^{\circ} \mathrm{C}$, sedangkan temperature coal pipe hasil dirty air test sebesar $134,3{ }^{\circ} \mathrm{F} \quad\left(56,8{ }^{\circ} \mathrm{C}\right)$. Hasil pengujian fineness pulverizer A ditunjukkan pada Tabel 2, fineness lolos ayakan 200 mesh dari sampel isokinetic pada coal pipe 1, 2, 3 dan 4 secara urut sebesar 64,53, 93,85, 89,71 dan 80,32 (\%wt) dengan nilai rata-rata 82,12 $\%$ wt.

Tabel 2 .

Fineness batubara pulverizer A

\begin{tabular}{cccccc}
\hline \multirow{2}{*}{$\begin{array}{c}\text { Ukuran } \\
\text { mesh }\end{array}$} & \multicolumn{5}{c}{$\begin{array}{c}\text { Coal Pipe } \\
(\% \text { wt })\end{array}$} \\
\hline 200 & 64,53 & 93,85 & 89,71 & 80,38 & $\mathbf{8 2 , 1 2}$ \\
150 & 75,72 & 96,80 & 94,84 & 88,81 & $\mathbf{8 9 , 0 4}$ \\
100 & 88,13 & 98,35 & 97,58 & 95,48 & $\mathbf{9 4 , 8 9}$ \\
48 & 99,49 & 99,52 & 99,47 & 99,69 & $\mathbf{9 9 , 5 4}$ \\
\hline
\end{tabular}


Hal ini menunjukkan bahwa tingkat kehalusan batubara yang dihasilkan oleh pulverizer A masih dalam kondisi baik sesuai rekomendasi EPRI untuk batubara tipe lignite maka fineness lolos 200 mesh disarankan dalam rentang $60-70 \%$ (EPRI, 1998).

Hasil dirty air test pulverizer B ditunjukkan pada Gambar 8, velocity dirty air pada coal pipe 1, 2, 3 dan 4 secara urut sebesar 31,19, 33,20, 36,00 dan $34,86(\mathrm{~m} / \mathrm{s})$ dengan rerata dirty air velocity sebesar $33,81 \mathrm{~m} / \mathrm{s}$. Berdasarkan nilai dirty air velocity tersebut maka didapat velocity deviation terhadap rerata velocity untuk coal pipe 1, 2, 3 dan 4 sebesar $7,75,-1,80,6,46$ dan 3,09 (\%). Pada coal pipe 1 sedikit terjadi under velocity karena nilai deviasi sebesar $-7,75 \%$, sedangkan pada coal pipe 3 sedikit terjadi over velocity sebesar $6,46 \%$ terhadap rerata.

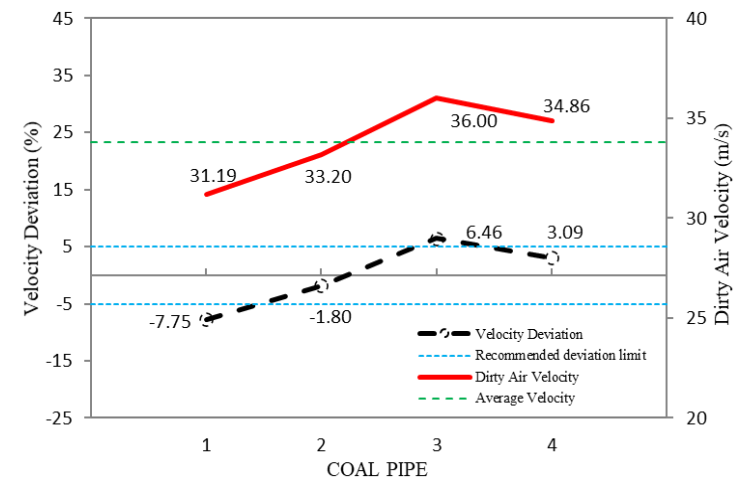

Gambar 8. Grafik dirty air velocity pulverizer B

Temperature keluaran mill B dari DCS menunjukkan $59,92{ }^{\circ} \mathrm{C}$, sedangkan temperature coal pipe hasil dirty air test sebesar $134,6^{\circ} \mathrm{F}\left(57.0^{\circ} \mathrm{C}\right)$. Hasil pengujian fineness pulverizer $\mathrm{B}$ ditunjukkan pada Tabel 3, fineness lolos ayakan 200 mesh dari sampel isokinetic pada coal pipe 1, 2, 3 dan 4 secara urut sebesar 71,55, 81,30, 92,10 dan 88,02 (\%wt) dengan nilai rata-rata $83,24 \%$ wt. Hal ini menunjukkan bahwa tingkat kehalusan batubara yang dihasilkan oleh pulverizer B dalam kondisi baik.

Tabel 3 .

Fineness batubara Pulverizer B

\begin{tabular}{cccccc}
\multicolumn{6}{c}{ Fineness batubara Pulverizer B } \\
\hline $\begin{array}{c}\text { Ukuran } \\
\text { mesh }\end{array}$ & 1 & 2 & 3 & 4 & Rerata \\
& \multicolumn{5}{c}{ Coal Pipe } \\
\hline 200 & 71,55 & 81,30 & 92,10 & 88,02 & $\mathbf{8 3 , 2 4}$ \\
150 & 82,71 & 89,33 & 96,37 & 93,41 & $\mathbf{9 0 , 4 5}$ \\
100 & 93,15 & 96,02 & 98,65 & 97,53 & $\mathbf{9 6 , 3 4}$ \\
48 & 99,80 & 99,74 & 99,67 & 99,80 & $\mathbf{9 9 , 7 5}$ \\
\hline
\end{tabular}

Hasil dirty air test pulverizer $\mathrm{C}$ ditunjukkan pada Gambar 9. Velocity dirty air pada coal pipe 1, 2, 3 dan 4 secara urut sebesar 29.96, 22.19, 27.71 dan $30.43(\mathrm{~m} / \mathrm{s})$ dengan rerata dirty air velocity sebesar $27.57 \mathrm{~m} / \mathrm{s}$. Berdasarkan nilai dirty air velocity tersebut maka didapat velocity deviation terhadap rerata velocity untuk coal pipe 1, 2, 3 dan 4 sebesar 8.66, -19.52, 0.51 dan $10.36(\%)$.

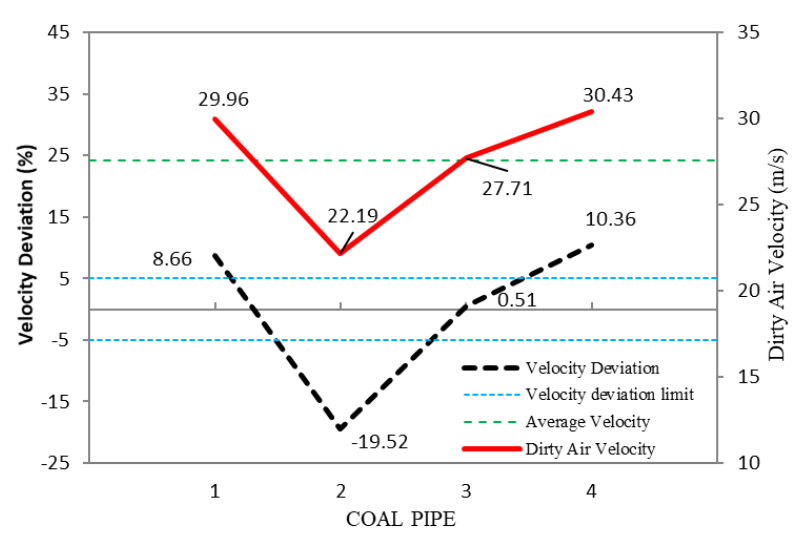

Gambar 9. Grafik dirty air velocity pulverizer C

Pada coal pipe 2 terjadi under velocity karena nilai deviasi sebesar $-19.52 \%$ terhadap rata-rata. Hal ini karena masih terdapat aliran turbulensi saat pembacaan tekanan dinamis pada coal pipe 2, sehingga hasil velocity dirty air kurang akurat sehingga perlu dilakukan pemindahan lokasi tap pengujian menjauh dari hambatan upstream.

Tabel 4 .

Fineness batubara Pulverizer C

\begin{tabular}{cccccc}
\multicolumn{6}{c}{ Fineness batubara Pulverizer C } \\
\hline $\begin{array}{c}\text { Ukuran } \\
\text { mesh }\end{array}$ & 1 & 2 & 3 & 4 & Rerata \\
& \multicolumn{5}{c}{$\begin{array}{c}\text { Coal Pipe } \\
(\%)\end{array}$} \\
\hline 200 & 67,64 & 62,40 & 91,04 & 74,74 & $\mathbf{7 3 , 9 6}$ \\
150 & 80,18 & 75,63 & 96,08 & 85,19 & $\mathbf{8 4 , 2 7}$ \\
100 & 91,34 & 88,78 & 98,62 & 93,52 & $\mathbf{9 3 , 0 6}$ \\
48 & 99,39 & 98,95 & 99,66 & 99,44 & $\mathbf{9 9 , 3 6}$ \\
\hline
\end{tabular}

Hasil pengujian fineness pulverizer $\mathrm{C}$ sesuai Tabel 4, fineness lolos ayakan 200 mesh dari sampel isokinetic pada coal pipe 1, 2, 3 dan 4 secara urut sebesar 67,64, 62,40, 91,04 dan 74,74 (\%wt) dengan nilai rerata $73,96 \%$ wt. Hal ini menunjukkan bahwa tingkat kehalusan batubara yang dihasilkan oleh pulverizer $\mathrm{C}$ masih dalam kondisi baik.

Hasil dirty air test pulverizer D ditunjukkan pada Gambar 10. Velocity dirty air pada coal pipe 1, 2, 3 dan 4 secara urut sebesar 16,93, 31,94, 36,65 dan $18,83(\mathrm{~m} / \mathrm{s})$ dengan rerata dirty air velocity sebesar $26,09 \mathrm{~m} / \mathrm{s}$.

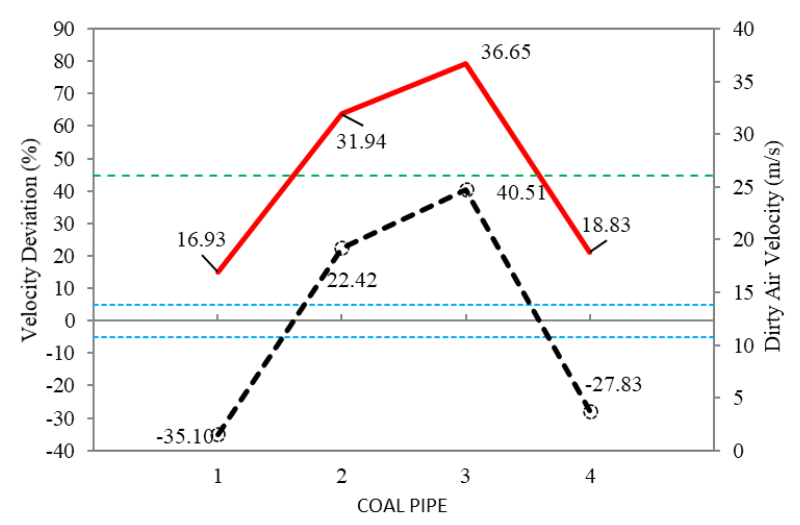

Gambar 10. Grafik dirty air velocity pulverizer D 
Berdasarkan nilai dirty air velocity tersebut didapat velocity deviation terhadap rerata velocity untuk coal pipe 1, 2, 3 dan 4 sebesar -35,10, 22,42, 40,51 dan $-27,83(\%)$. Pada coal pipe 1 dan 4 terjadi under velocity karena nilai deviasi sebesar -35,10 dan $-27,83(\%)$ terhadap rata-rata. Hal ini karena adanya aliran turbulensi yang terbaca sebagai tekanan nol saat pengambilan data tekanan dinamis, sehingga nilai velocity dirty air pada coal pipe tersebut kurang akurat. Untuk menghindari aliran turbulensi tersebut perlu memindahkan posisi tap test lebih menjauh dari hambatan upstream atau digeser ke posisi atas.

Temperature keluaran mill D pada DCS menunjukkan $59,9{ }^{\circ} \mathrm{C}$, sedangkan temperature coal pipe hasil dirty air test sebesar $134,6{ }^{\circ} \mathrm{F}\left(57,0^{\circ} \mathrm{C}\right)$.

Tabel 5

Fineness batubara Pulverizer D

\begin{tabular}{cccccc}
\hline $\begin{array}{c}\text { Ukuran } \\
\text { mesh }\end{array}$ & \multicolumn{5}{c}{$\begin{array}{c}\text { Coal Pipe } \\
(\% \text { wt })\end{array}$} \\
& 1 & 2 & 3 & 4 & Rerata \\
\hline 200 & 64,67 & 84,10 & 93,01 & 74,74 & $\mathbf{7 9 , 1 3}$ \\
150 & 75,72 & 91,44 & 96,62 & 83,76 & $\mathbf{8 6 , 8 9}$ \\
100 & 86,71 & 96,54 & 98,64 & 91,88 & $\mathbf{9 3 , 4 4}$ \\
48 & 98,01 & 99,66 & 99,71 & 98,97 & $\mathbf{9 9 , 0 9}$ \\
\hline
\end{tabular}

Hasil pengujian fineness pulverizer D ditunjukkan pada Tabel 5, fineness lolos ayakan 200 mesh dari sampel isokinetic pada coal pipe 1,2, 3 dan 4 secara urut sebesar $64,67,84,10,93,01$ dan 74,74 (\%wt) dengan nilai rata-rata $79,13 \%$ wt. Hal ini menunjukkan bahwa tingkat kehalusan batubara yang dihasilkan oleh pulverizer D masih dalam kondisi baik.

Hasil dirty air test pulverizer E ditunjukkan pada Gambar 11. Velocity dirty air pada coal pipe 1, 2, 3 dan 4 secara urut sebesar 30,11, 34,33, 31,93 dan $33,95(\mathrm{~m} / \mathrm{s})$ dengan rerata dirty air velocity sebesar $32,58 \mathrm{~m} / \mathrm{s}$.

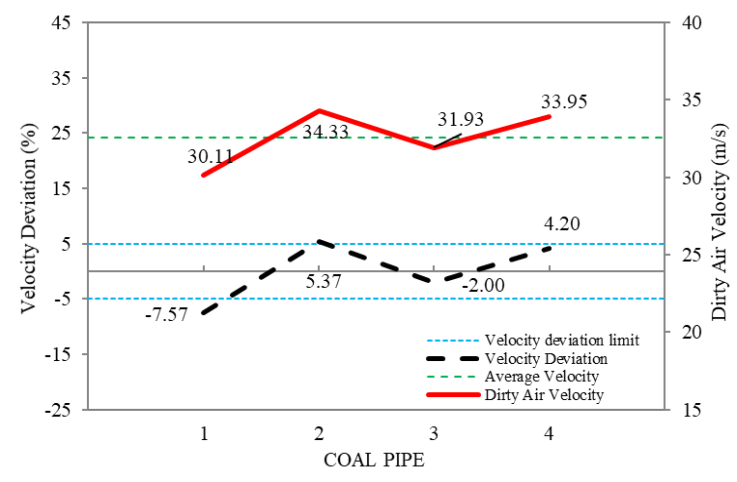

Gambar 11. Grafik dirty air velocity pulverizer E

Berdasarkan nilai dirty air velocity diatas maka didapat velocity deviation terhadap rerata velocity untuk coal pipe 1, 2, 3 dan 4 sebesar -7,57, 5,37, -2,00 dan 4,20 (\%). Pada coal pipe 1 terjadi under velocity karena nilai deviasi sebesar $-7,57 \%$. Temperature outlet mill yang ditunjukkan pada DCS sebesar $59.2^{\circ} \mathrm{C}$, sedangkan temperatur pada coal pipe hasil dirty air test sebesar $137,0^{\circ} \mathrm{F}\left(58,3^{\circ} \mathrm{C}\right)$.

Tabel 6.

Fineness batubara Pulverizer E

\begin{tabular}{cccccc}
\hline \multirow{2}{*}{$\begin{array}{c}\text { Ukuran } \\
\text { mesh }\end{array}$} & \multicolumn{5}{c}{$\begin{array}{c}\text { Coal Pipe } \\
(\% \text { wt) }\end{array}$} \\
& 1 & 2 & 3 & 4 & Rerata \\
\hline 200 & 66,52 & 72,71 & 61,60 & 71,74 & 68,14 \\
150 & 79,25 & 84,31 & 74,04 & 82,59 & 80,04 \\
100 & 90,67 & 93,04 & 86,16 & 92,00 & 90,47 \\
48 & 99,38 & 99,55 & 99,19 & 99,68 & 99,45 \\
\hline
\end{tabular}

Hasil pengujian fineness pulverizer $\mathrm{E}$ ditunjukkan pada Tabel 6, fineness lolos ayakan 200 mesh dari sampel isokinetic pada coal pipe 1,2, 3 dan 4 secara urut sebesar 66,52, 72,71, 61,60 dan 71,74 (\%wt) dengan nilai rata-rata 68,14\%wt.

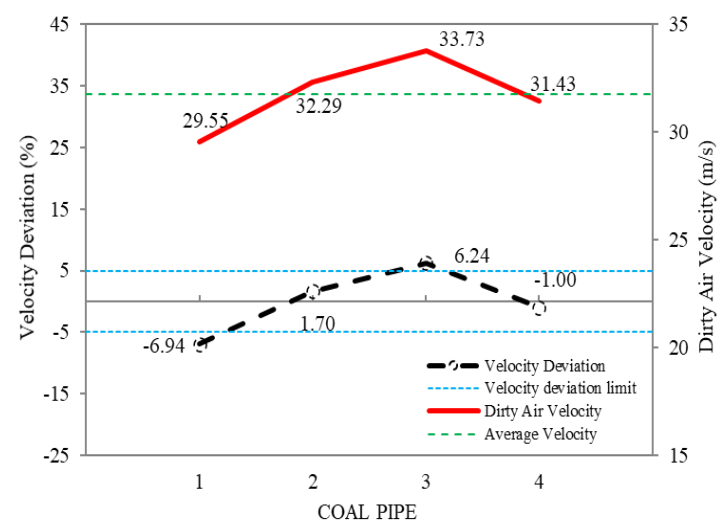

Gambar 12. Grafik dirty air velocity pulverizer F

Hasil dirty air test pulverizer F sesuai Gambar 12.Velocity dirty air pada coal pipe 1, 2, 3 dan 4 secara urut sebesar 29,55, 32,29, 33,73 dan 31,43 $(\mathrm{m} / \mathrm{s})$ dengan rerata dirty air velocity sebesar 31,75 $\mathrm{m} / \mathrm{s}$. Berdasarkan nilai dirty air velocity diatas maka didapat velocity deviation terhadap rerata velocity untuk coal pipe 1, 2, 3 dan 4 sebesar -6,94, 1,70, 6,24 dan $-1.00(\%)$.

Pada coal pipe 1 sedikit terjadi under velocity dengan nilai deviasi sebesar $-6,94 \%$, sedangkan pada coal pipe 3 sedikit terjadi over velocity sebesar 6,24 $\%$. Untuk menyeimbangkan velocity dirty air dapat dilakukan dengan menyesuaikan pembukaan orifice, atau dengan menaikkan temperature outlet mill hingga mencapai titik optimal.

Tabel 7 . Fineness batubara Pulverizer $F$

\begin{tabular}{cccccc}
\hline $\begin{array}{c}\text { Ukuran } \\
\text { mesh }\end{array}$ & \multicolumn{5}{c}{$\begin{array}{c}\text { Coal Pipe } \\
(\% \text { wt })\end{array}$} \\
\hline 200 & 76,57 & 72,25 & 82,07 & 82,82 & $\mathbf{7 8 , 4 3}$ \\
150 & 86,01 & 82,57 & 89,11 & 90,10 & $\mathbf{8 6 , 9 5}$ \\
100 & 93,96 & 92,27 & 94,98 & 95,38 & $\mathbf{9 4 , 1 5}$ \\
48 & 99,57 & 99,54 & 99,48 & 99,37 & $\mathbf{9 9 , 4 9}$ \\
\hline
\end{tabular}


Hasil pengujian temperature outlet mill dari DCS sebesar $60,3{ }^{\circ} \mathrm{C}$, sedangkan temperature ratarata pada coal pipe hasil dirty air test sebesar $57,7^{\circ} \mathrm{C}$ $\left(139,9^{\circ} \mathrm{F}\right)$. Hasil pengujian fineness pulverizer $\mathrm{F}$ sesuai Tabel 7, fineness lolos ayakan 200 mesh dari sampel hasil isokinetic coal sampling pada coal pipe 1, 2, 3 dan 4 secara urut sebesar 76,57, 72,25, 82,07 dan 82,82 (\%wt) dengan nilai rerata $78,43 \%$ wt. Hal ini menunjukkan bahwa tingkat kehalusan batubara yang dihasilkan oleh pulverizer $\mathrm{F}$ masih dalam kondisi baik.

Pada beberapa coal pipe dari pulverizer A hingga $\mathrm{F}$, terjadi under and over velocity dan terjadi penurunan temperatur dari keluaran mill yang terbaca di DCS dengan temperatur pada coal pipe yang masih lebih rendah dari rekomendasi $65{ }^{\circ} \mathrm{C}$ untuk penggunaan batubara dengan volatile matter 31,66$33,23 \%$ (POWER, 2017). Dengan melakukan penyesuaian orifice atau meningkatkan temperatur keluaran mill hingga mencapai titik optimum dapat menyeimbangkan kecepatan aliran campuran udara dan bahan bakar dari tiap pulverizer. Peningkatan temperatur keluaran mill dapat mengurangi kemungkinan terbentuknya gumpalan pada serbuk batubara sehingga meningkatkan distribusi keseimbangan penyebaran serbuk batubara pada aliran bahan bakar.

\section{PENUTUP}

Hasil pengujian dirty air pada coal pipe keluaran pulverizer D, C dan A menunjukkan beberapa coal pipe masih mengalami turbulensi yang menyebabkan pembacaan dirty air velocity tidak akurat. Lokasi taping pengujian pada pulverizer tersebut direkomendasikan untuk dipindahkan dengan jarak lima kali diameter pipa ke arah upstream menjauhi lokasi hambatan seperti belokan pada jalur pipa. Sedangkan pada hasil pengujian dirty air pada coal pipe keluaran pulverizer F, E dan B menunjukkan hasil yang baik dengan kecepatan aliran udara dan bahan bakar pada tiap coal pipe relative seragam. Temperatur keluaran mill pada pulverizer A, B, C, D, E dan F menunjukkan nilai yang lebih rendah dari rekomendasi untuk PLTU batubara yang menggunakan batubara jenis lignite yaitu $65{ }^{\circ} \mathrm{C}$. Karena pada unit pembangkit PLTU yang diuji tidak terdapat orifice pada tiap coal pipe maka disarankan untuk meningkatkan temperatur keluaran mill diatas $65^{\circ} \mathrm{C}$ untuk membantu keseimbangan laju alir keluaran batubara dari tiap pulverizer. Hasil pemeriksaan ukuran serbuk batubara pada tiap pulverizer menggunakan isokinetic sampling menunjukkan hasil yang masih cukup baik dengan rerata persentase batubara yang lolos ayakan 200 mesh untuk pulverizer A, B, C, D, $\mathrm{E}$ dan $\mathrm{F}$ adalah 82.12, 83,24, 73.96, 79.13, 68.14 and $78.43 \mathrm{wt} \%$.

\section{UCAPAN TERIMA KASIH}

Terima kasih kepada PT PLN (Persero) yang telah mendukung pelaksanaan penelitian ini.

\section{DAFTAR PUSTAKA}

ASME. (1969). Coal Pulverizer-PTC 4.2. ASME.

ASME. (2010). Performance Monitoring Guidelines for Power Plants-PTC PM - 2010. ASME.

ASTM. (2007). ASTM D-197-Standard Test Method for Sampling and Fineness Test of Pulverized Coal. ASTM.

Brown, O., \& McClellan, A. (2017, September 5). Combustion, Reliability, and Heat Rate Improvements Through Mill Performance and Applying the Essentials. ASME 2017 Power Conference Joint With ICOPE-17 collocated with the ASME 2017 11th International Conference on Energy Sustainability, the ASME 2017 15th International Conference on Fuel Cell Science, Engineering and Technology, and the ASME 2017 Nuclear Forum. https://doi.org/10.1115/POWERICOPE2017-3087

EPRI. (1998). Heat Rate Improvement Reference Manual (TR-109546). EPRI.

Li, Q., \& Yao, G. (2017). Improved coal combustion optimization model based on load balance and coal qualities. Energy, 132, 204-212. https://doi.org/10.1016/j.energy.2017.05.06 8

Nugroho, B. A., \& Ichsani, D. (2019). Experimental study: The effect of the variation of the mill air fuel ratio on fineness in the pulverizer of the $600 \mathrm{MW}$ Indonesian steam power plant. AIP Conference Proceedings, 2187(1), 020016. https://doi.org/10.1063/1.5138271

POWER. (2010, October 7). Pulverized Coal Pipe Testing and Balancing. POWER Magazine. https://www.powermag.com/pulverizedcoal-pipe-testing-and-balancing/

POWER. (2011, December 1). Pulverizers 101: Part III. POWER Magazine. https://www.powermag.com/pulverizers101-part-iii/

POWER. (2017, December 1). Improve Power Plant Heat Rate with a Pulverizer Performance Program. POWER Magazine. https://www.powermag.com/improvepower-plant-heat-rate-with-a-pulverizerperformance-program/

Prasetyo, I. D., \& Prabowo. (2019). Experimental study effect of classifier pulverizer opening setting variation on fineness production passed 200 mesh. AIP Conference Proceedings, 2187(1), 020014. https://doi.org/10.1063/1.5138269

Schreiber, M., Haug, M., Starke, M., Kock, R., \& Turoni, F. (2008). Online measurement of coal fineness and air-fuel ratio inside the coal pipe. PowerGen International, 2-4.

Storm, D. \& Consultant. (2009). Applying the Fundamentals for Best Heat Rate 
Performance of Pulverized Coal Fueled Boilers.

Wiatros-Motyka, M. (2016). Optimising fuel flow in pulverised coal and biomass-fired boilers. IEA Clean Coal Centre; Report, CCC/263; IEA: London, UK.
Żymełka, P., Nabagło, D., Janda, T., \& Madejski, P. (2017). Online monitoring system of air distribution in pulverized coal-fired boilers based on numerical modeling. Archives of Thermodynamics, Vol. 38, 4, 109-125. https://doi.org/10.1515/aoter-2017-0027 